\title{
SUSTAINABLE APPROACH TO MITIGATION OF CO, EMISSION
}

\author{
ZRÓWNOWAŻONE METODY OGRANICZANIA EMISJI CO
}

\begin{abstract}
The discussion about greenhouse gases emission mitigation focuses on the reduction of fossil fuels usage, which is extremely costly from the economic and social viewpoint. The analyses of $\mathrm{CO}_{2}$ and $\mathrm{CH}_{4}$ fluxes in the environment showed that intensifying natural photosynthesis and respiration process may significantly contribute to the mitigation of greenhouse gases emission. It has been proven that the intensity of photosynthesis in land ecosystems could compensate for the increase of $\mathrm{CO}_{2}$ emission from anthropological sources.
\end{abstract}

Keywords: greenhouse effect, $\mathrm{CO}_{2}$ emission, $\mathrm{CH}_{4}$ emission

\section{Introduction}

The paradigms of sustainable development, inter- and intergenerational equity set the general theoretical directions for the development of human civilization. The problem is that the dominant model of socio-economical relations, based on absolute competition of everyone with everyone, is not conducive to the implementation of sustainable development paradigms in the social sphere, where inequalities arise rapidly, as well as due to the excessive exploitation of non-renewable resources of Earth. The current status of the world is best reflected in the expression 'grow or die'. The problem of climatic changes is inherently related to the depletion of fossil fuels. One-way approach to counteracting the global warming through thorough changes in the energy policy aimed at cutting $\mathrm{CO}_{2}$ emission is not sustainable. It turned out that broad implementation of biofuels leads to serious environmental and economic consequences. More importantly, in many cases burning biofuels increases the $\mathrm{CO}_{2}$ emission. As the plantations of biofuel crops are established in the place of felled tropical forests, the negative consequences for the environment arise. Additionally, the development of biofuel crops cultivation caused

\footnotetext{
${ }^{1}$ Department of Chemistry, Hunter College of the City University of New York, 695 Park Avenue, New York, NY 10021, United States

${ }^{2}$ Faculty of Agrobioengineering, Natural Sciences University, ul. Akademicka 13, 20-950 Lublin, Poland

${ }^{3}$ Faculty of Environmental Engineering, Lublin University of Technology, ul. Nadbystrzycka 40B, 20-618 Lublin, Poland, phone +48 81538 4410, fax +48 81538 1997, email: w.cel@ pollub.pl

${ }^{4}$ School of Environmental and Recourse Science, Zhejiang Agriculture and Forestry University, Hangzhou 311300, China

*Corresponding author: w.cel@pollub.pl
} 
an increase in food price, which stands in contradiction to the intergenerational equity paradigm, an important sustainable development criterion [1-4]. It was erroneously assumed that burning biofuel generates the equal amount of $\mathrm{CO}_{2}$ to the one absorbed in the process of growing. These calculations do not take into account the energy used in cultivation, harvesting and processing. The implementation of LCA showed that in the case of such biofuels as corn ethanol or biodiesel from sunflower seed oil, the energy consumed in the production cycle is greater than the energy produced by burning them; therefore, the implementation of these biofuels increases the $\mathrm{CO}_{2}$ emission instead of decreasing it [5].

Hence, it is necessary to analyze the entire $\mathrm{CO}_{2}$ cycle in the Earth ecosystem with the use of LCA technique and to evaluate potential consequences of each undertaking.

While there is no doubt about the presence of global warming, there are discrepancies in calculating the projected changes. The temperature increase forecast by IPCC 2013 is disputed by Lindzen [6], an outstanding American climatologist; however, he does not negate the need of counteracting the increase in average temperature on Earth.

\section{Methods of counteracting the increase of $\mathrm{CO}_{2}$ concentration in atmosphere}

Recommended methods of mitigating $\mathrm{CO}_{2}$ emissions mainly boil down to reducing the $\mathrm{CO}_{2}$ emissions from the burning processes. While burning fossil fuels is indeed the main cause of the increase of $\mathrm{CO}_{2}$ concentration in atmosphere, focusing solely on this source renders the previous counteractions ineffective. Although, we manage to attain the annual $0.3 \%$ increase in decarbonation of fuels, it is nullified by the $2 \%$ growth of overall energy consumption each year [7]. It seems that greater possibilities of reducing $\mathrm{CO}_{2}$ concentration in atmosphere can be achieved by amplifying photosynthesis in land ecosystems and lowering $\mathrm{CO}_{2}$ emissions from soil. Both land ecosystems and soil exchange large streams of $\mathrm{CO}_{2}$ from the atmosphere. Absorption of $\mathrm{CO}_{2}$ taking place in the process of photosynthesis in land ecosystems amounts to $123 \pm 8$ billion $\mathrm{Mg}$ of $\mathrm{C}_{\mathrm{CO}_{2}} /$ year. Simultaneously, $60 \pm 3$ billion $\mathrm{Mg}$ of $\mathrm{C}_{\mathrm{CO}_{2}}$ /year are emitted by land ecosystems in the process of breathing and the same amount of $\mathrm{CO}_{2}$ is generated by soil [8].

Approximately half of the $\mathrm{CO}_{2}$ amount emitted from anthropogenic sources is absorbed by seas and oceans, as well as land ecosystems. The remaining amount of $4.8 \pm 0.2$ billion $\mathrm{Mg}$ of $\mathrm{C}_{\mathrm{CO}_{2}}$ /year stays in the atmosphere and increases its $\mathrm{CO}_{2}$ concentration. This amount is just a small part of the two main $\mathrm{CO}_{2}$ flows in the atmosphere, ie photosynthesis and sea and ocean absorption. A slight modification of these natural flows, with the average of $2 \%$ could neutralize the $\mathrm{CO}_{2}$ emission from anthropogenic sources.

Is that possible?

The greatest possibilities of mitigating $\mathrm{CO}_{2}$ concentration in atmosphere are presented by photosynthesis in land ecosystems and slowing down the $\mathrm{CO}_{2}$ emission from soil. One of the key factors which allow the intensification of photosynthesis in land ecosystems is increasing the afforestation by both slowing down the cutting of tropical forests and afforestation of other areas, especially the ones with poor soil quality. In this way, over a hundred years the absorption of $\mathrm{CO}_{2}$ by land ecosystems can be boosted by 40-70 billion $\mathrm{Mg}$ of $\mathrm{C}_{\mathrm{CO}_{2}}[9,10]$. Photosynthesis can also be intensified by nitrogen and 
phosphorus fertilizers; however, while the production of nitrogen fertilizers is virtually unlimited, the phosphorus compounds are mined and thus finite. Therefore, attention should be drawn to recycling the unused biomass that contains phosphorus compounds back to soil. One possibility that has not been taken advantage of is growing the after-crops, which can additionally absorb $\mathrm{CO}_{2}$. Utilizing the after-crops as a fertilizer can significantly increase the absorption of $\mathrm{CO}_{2}$ through photosynthesis.

It would be enough to increase the $\mathrm{CO}_{2}$ absorption through photosynthesis by $2.2 \%$ to mitigate $50 \%$ of $\mathrm{CO}_{2}$ emission from anthropogenic sources that raise the carbon dioxide concentrations in atmosphere. Approximately $50 \%$ of emissions from anthropogenic sources are absorbed by the increasing absorption of land ecosystems as well as seas and oceans that is caused by the elevation of $\mathrm{CO}_{2}$ concentration in atmosphere. The data show that more attention should be devoted to the amplification of $\mathrm{CO}_{2}$ absorption through photosynthesis.

The second important subsystem that is responsible for $\mathrm{CO}_{2}$ emissions to the atmosphere are soils, which emit ca. 60 billion $\mathrm{Mg}$ of $\mathrm{C}_{\mathrm{CO}_{2}}$ /year through the processes of decomposing organic matter and breathing of microorganisms.

Tillage is conductive to the intensification of organic matter oxidation. Substituting tillage with other cultivation methods may reduce the $\mathrm{CO}_{2}$ emissions from this subsystem to the atmosphere. The $4 \%$ reduction of the soil microorganisms breathing intensity would offset the emissions from anthropogenic sources (approximately 50\% of total emission) that raise the $\mathrm{CO}_{2}$ concentration in atmosphere.

In the case of seas and oceans, the increase of $\mathrm{CO}_{2}$ absorption can be achieved through the growth of plankton which benefits from spreading iron and phosphorus compounds. An experiment involving spreading of iron compounds over a $10 \mathrm{~km}^{2}$ area [11] yielded moderate results. While the growth of algae has been noticed, the amount of zooplankton that feeds on algae increased as well. The majority of algae devoured by zooplankton were remineralized back to $\mathrm{CO}_{2}$ in the breathing process.

However, over the half of $\mathrm{CO}_{2}$ amount absorbed additionally through fertilization with iron compounds, settled on the depth of below $1000 \mathrm{~m}$ [12]. Some researchers suggest [13, 14] that certain amount of carbon in the form of biomass can be permanently disposed of by sinking it in the ocean depths. Fertilizing the surface of ocean with iron for a hundred years could lower the $\mathrm{CO}_{2}$ concentration in atmosphere by 15 [15] to $33 \mathrm{ppm}[16,17]$ carried out simulations which demonstrate that fertilizing only the equatorial oceans for a hundred years could lower the $\mathrm{CO}_{2}$ concentration in atmosphere by $66 \mathrm{ppm}$. Other researchers [18] suggested the solution relying on elevating the lower layers of ocean water, richer in nutrients in order to boost algae growth. However, it seems that the above-mentioned methods are not feasible.

The proposals of removing $\mathrm{CO}_{2}$ from atmosphere through intensification of erosion should be noted as well. The silicates found in the Earth's crust such as olivine and basalt react with $\mathrm{CO}_{2}$ changing into soluble form. Kelemen and Mater [19] believe that spreading these ground minerals over humid, tropical areas may lead to absorption of 0.25-1 billion $\mathrm{Mg}$ of $\mathrm{C}_{\mathrm{CO}_{2}}$ /year. The dissolved minerals would flow with water into oceans [20]. Renforth [21] estimates that using the silicates found in the Great Britain with this method would remove 100 billion $\mathrm{Mg}$ of $\mathrm{C}_{\mathrm{CO}_{2}}$ /year .

In their calculations, the above-mentioned authors did not take into account the energy inputs and, consequently, the $\mathrm{CO}_{2}$ emissions related to the production of energy necessary 
for mining, grinding, transporting and spreading the minerals. It seems then that removing $\mathrm{CO}_{2}$ through the intensification of erosion is also not very feasible from the practical viewpoint.

In sum, the greatest potential of mitigating $\mathrm{CO}_{2}$ concentration in atmosphere is displayed by the methods relying on the amplification of photosynthesis process, especially in land ecosystems on the one hand, and lowering $\mathrm{CO}_{2}$ emission from soil on the other.

It seems that proper manipulation of these processes may freeze the $\mathrm{CO}_{2}$ concentration in atmosphere, without any significant and costly changes in energy management - which is more beneficial according to the sustainable development principles.

Finally, we would like to draw the attention to $\mathrm{CH}_{4}$ which is the second most prevalent greenhouse gas. Three most important sources of its emission include the rice field cultivation emissions, ruminants' - especially cattle - emissions, and the municipal wastes emission. Decreasing the emission from the two first sources is difficult. Rice is the basis of alimentation of a great share of population. It is not easy to change dietary habits either, as both milk and beef are important part of diet of a great number of people.

However, there are ways of lowering the $\mathrm{CH}_{4}$ emissions from municipal waste deposits by employing cheap, biologically active topsoil which can be used in methane oxidization [22-24] or in automatic biofilters [25] or through the addition of wastewater sludge that intensifies the methane production, allowing it to be used as a source of energy [26].

\section{Conclusions}

The actions taken against the global climate changes, especially the ones mitigating $\mathrm{CO}_{2}$ emissions from anthropogenic sources, have a significant impact on economic processes.

The article showed that the natural processes of $\mathrm{CO}_{2}$ emission and absorption from atmosphere are many times more important than the anthropogenic sources. The authors draw the attention to the fact that intensifying photosynthesis process by approximately $2.2 \%$ would be enough to freeze the $\mathrm{CO}_{2}$ concentration increase in atmosphere. A similar result can be achieved by means of lowering the $\mathrm{CO}_{2}$ emission from soil through changes in cultivation methods.

Intensification of natural methods that aim at limiting the increase of $\mathrm{CO}_{2}$ in atmosphere is more sustainable because it bears lesser social costs.

\section{References}

[1] Dasgupta P. Land access and food security for forest dwellers: an economic analysis for India. Problems of Sustainable Development/Problemy Ekorozwoju. 2013;8:27-37. www.ekorozwoj.pol.lublin.pl/no16/e.pdf.

[2] Duran J, Golusin M, Ivanovic OM, Javanovic L, Andrejevic A. Renewable energy and socio-economic development in the European Union. Problems of Sustainable Development/Problemy Ekorozwoju. 2013;8(1):105-114. www.ekorozwoj.pol.lublin.pl/no15/k.pdf.

[3] Ecimovic T, Haw R, Kondrashin I, Raoul W, Vivanco GF. Philosophy of the Sustainable Development and the Sustainable Future of Humankind - the Survival of Humanity. Problems of Sustainable Development/Problemy Ekorozwoju. 2014;9(2):7-25. www.ekorozwoj.pol.lublin.pl/no18/d.pdf.

[4] Venkatesh G. Sisyphean struggle or Pyrrhic victory? Problems of Sustainable Development/Problemy Ekorozwoju. 2014;9(2):73-77. www.ekorozwoj.pol.lublin.pl/no18/j.pdf.

[5] Pimentel D. Energy production from maize. Problemy Ekorozwoju/Problems of Sustainable Development. 2012;7(2):15-22. www.ekorozwoj.pol.lublin.pl/no14/c.pdf. 
[6] Lindzen RS. Global warming: the origin and nature of the alleged scientific consensus. Problems of Sustainable Development/Problemy Ekorozwoju. 2010;5:13-28. www.ekorozwoj.pol.lublin.pl/no10/b.pdf.

[7] Gruber N, Hauri C, Lachkar Z, Loher D, Frolicher T, Plattner GK. Rapid progression of ocean acidification in the California Current System. Science. 2012;337: 220-223. DOI: 10.1126/science.1216773.

[8] IPCC. Fourth Assessment Report. Carbon and other Biochemical Cycles. 2014. www.ipcc.ch/pdf/press/ipcc_leaflets_2010/ipcc_ar5_leaflet.pdf.

[9] House JI, Prentice IC, Le Quere C. Maximum impacts of future reforestation or deforestation on atmospheric $\mathrm{CO}_{2}$. Global Change Biol. 2002;8:1047-1052. DOI: 10.1046/j.1365-2486.2002.00536.x.

[10] Canadell JG, Raupach MR. Managing forests for climate mitigation. Science. 2008;320:1456-1457. DOI: 10.1126/science.1155458.

[11] Boyd PW, Jickells T, Law CS, Blain S, Boyle EA, Buesseler KO, et al. Mesoscale iron enrichment experiments 1993-2005: Synthesis and future directions. Science. 2007;315:612-617. DOI: 10.1126/science.1131669.

[12] Smetacek V, Klaas C, Stras VH, Assmy P, Montresor M, Cisewski B, et al. Deep carbon export from a Southern Ocean iron-fertilized diatom bloom. Nature. 2012:487;313-319. DOI: 10.1038/nature11229.

[13] Buesseler KO, Andrews JE, Pike SM, Charette MA. The effects of iron fertilization on carbon sequestrion in the Southern Ocean. Science. 2004;304:414-417. DOI: 10.1126/science.1086895.

[14] Blain S, Quéguiner B, Armand L, Belviso S, Bombled B, Bopp L, et al. Effect of natural iron fertilization on carbon sequestration in the Southern Ocean. Nature. 2007;446:1070-1074. DOI: 10.1038/nature05700.

[15] Zeebe RE, Archer D. Feasibility of ocean fertilization and its impact on future atmospheric $\mathrm{CO}_{2}$ levels. Geophys Res Lett. 2005;32:970-978. DOI: 10.1029/2005GL022449.

[16] Aumont O, Boop L. Globalizing results from ocean in situ iron fertilization studies. Global Biogeochem Cycles. 2006;20:GB2017. DOI: 10.1029/2005GB002591.

[17] Jin $\mathrm{X}$, Gruber N. Offsetting the radiative benefit of ocean iron fertilization by enhancing $\mathrm{N}_{2} \mathrm{O}$ emissions. Geophys Res Lett. 2003;30(24):OCE3-1-OCE3-4. DOI: 10.1029/2003GL018458.

[18] Lovelock JE, Rapley CG. Ocean pipes could help the Earth to cure itself. Nature. 2007;449:403-403. DOI: 10.1038/449403a.

[19] Kelemen PB, Matter J. In situ carbonation of peridotite for $\mathrm{CO}_{2}$ storage. Proc National Acad Sci USA. 2008;105:17295-17300. DOI: 10.1073/pnas.0805794105.

[20] Schuiling RD, Krijgsman P. Enhanced weathering: An effective and cheap tool to sequester $\mathrm{CO}_{2}$. Climate Change. 2006;74:349-354. DOI: 10.1007/s10584-005-3485-y.

[21] Renforth P. The potential of enhanced weathering in the UK. Int J Greenhouse Gas Control. 2012;10:229-243. DOI: 10.1016/j.ijggc.2012.06.011.

[22] Stępniewski W, Pawłowska M. A Possibility to Reduce Methane Emission from Landfills by Its Oxidation in the Soil Cover. Chemistry from the Protection of the Environment 2. Environmental Science Research. New York: Plenum Press; 1996;51:75-92.

[23] Pawłowska M, Siepak J. Enhancement of methanogenesis at a municipal landfill site by addition of sewage sludge. Environ Eng Sci. 2006;23(4):673-679. DOI: 10.1089/ees.2006.23.673

[24] Pawłowska M, Siepak J. Biochemical reduction of methane emission from landfills. Environ Eng Sci. 2006;23(4):666-672. DOI: 10.1089/ees.2006.23.666.

[25] Pawłowska M, Rożej A, Stępniewski W. The effect of bed properties on methane removal in an aerated biofilter - model studies. Waste Manage. 2011;31(5):903-913. DOI: 10.1016/j.wasman.2010.10.005.

[26] Pawłowska M, Siepak J, Pawłowski L, Pleczyński J. Method for intensification of methane production in refuse collection depot. 2008. Patent no EP 08165558. 


\title{
ZRÓWNOWAŻONE METODY OGRANICZANIA EMISJI CO
}

\author{
${ }^{1}$ Wydział Chemii, Hunter College, Nowy Jork, USA \\ ${ }^{2}$ Wydział Agrobioinżynierii, Uniwersytet Przyrodniczy, Lublin \\ ${ }^{3}$ Wydział Inżynierii Środowiska, Politechnika Lubelska, Lublin \\ ${ }^{4}$ Wydział Ochrony Środowiska i Zasobów, Uniwersytet Rolnictwa i Leśnictwa, Zhejiang, Chiny
}

\begin{abstract}
Abstrakt: Dyskusja o ograniczeniu emisji gazów cieplarnianych koncentruje się na redukcji użycia węglowych paliw kopalnych, co jest niezwykle kosztowne z ekonomicznego i społecznego punktu widzenia. Analizując przepływy $\mathrm{CO}_{2} \mathrm{i} \mathrm{CH}_{4} \mathrm{w}$ środowisku wykazano, że intensyfikacja procesów naturalnych fotosyntezy i oddychania w ekosystemie Ziemi może w znacznym stopniu przyczynić się do redukcji emisji gazów cieplarnianych. Wykazano, że zintensyfikowanie fotosyntezy w ekosystemach lądowych mogłoby zrekompensować wzrost emisji $\mathrm{CO}_{2}$ ze źródeł antropogenicznych.
\end{abstract}

Słowa kluczowe: efekt cieplarniany, emisja $\mathrm{CO}_{2}$, emisja $\mathrm{CH}_{4}$ 